\title{
Pathophysiology of Chronic Tubulo-Interstitial Disease in Rats Interactions of Dietary Acid Load, Ammonia, and Complement Component C3
}

\author{
K. A. Nath, M. K. Hostetter, and T. H. Hostetter \\ Departments of Medicine and Pediatrics, School of Medicine, University of Minnesota, Minneapolis, Minnesota 55455
}

\begin{abstract}
The human end-stage kidney and its experimental analogue, the remnant kidney in the rat, exhibit widespread tubulointerstitial disease. We investigated whether the pathogenesis of such tubulo-interstitial injury is dependent upon adaptive changes in tubular function and, in particular, in ammonia production when renal mass is reduced. Dietary acid load was reduced in $1 \frac{3}{4}$-nephrectomized rats by dietary supplementation with sodium bicarbonate $\left(\mathrm{NaHCO}_{3}\right)$, while control rats, paired for serum creatinine after $1 \frac{3}{4}$ nephrectomy, were supplemented with equimolar sodium chloride. After 4-6 wk, $\mathrm{NaHCO}_{3}$ supplemented rats demonstrated less impairment of tubular function as measured by urinary excretory rates for total protein and low molecular weight protein and higher transport maximum for para-aminohippurate per unit glomerular filtration rate, less histologic evidence of tubulo-interstitial damage, less deposition of complement components $\mathrm{C} 3$ and $\mathrm{C5b}-9$, and a lower renal vein total ammonia concentration. Such differences in tubular function could not be accounted for simply on the basis of systemic alkalinization, and differences in tubular injury could not be ascribed to differences in glomerular function. Because nitrogen nucleophiles such as ammonia react with $\mathrm{C} 3$ to form a convertase for the alternative complement pathway, and because increased tissue levels of ammonia are associated with increased tubulo-interstitial injury, we propose that augmented intrarenal levels of ammonia are injurious because of activation of the alternative complement pathway. Chemotactic and cytolytic complement components are thereby generated, leading to tubulo-interstitial inflammation. Thus, alkali supplementation reduces chronic tubulo-interstitial disease in the remnant kidney of the rat, and we propose that this results, at least in part, from reduction in cortical ammonia and its interaction with the alternative complement pathway.
\end{abstract}

\section{Introduction}

Chronic tubulo-interstitial disease dominates the structural disarray of the end-stage kidney in humans $(1,2)$, as well as in its experimental analogue, the remnant kidney in the rat $(3,4)$. These structural abnormalities are functionally significant in that various histologic indices of tubulo-interstitial disease correlate quite closely with levels of both hemodynamic and tubular transport functions in a variety of human renal diseases $(1,2)$. The mechanisms by which tubulo-interstitial injury

Received for publication 14 September 1984 and in revised form 20 February 1985.

J. Clin. Invest.

(c) The American Society for Clinical Investigation, Inc.

0021-9738/85/08/0667/09 \$1.00

Volume 76, August 1985, 667-675 arise, and the reasons for continuing damage even in primary glomerular diseases are unknown. Recently, support has appeared for the hypothesis that adaptive changes in nephron function underlie nephron injury: in particular, that compensatory increments in ultrafiltration pressure that occur in remnant glomeruli constitute a mechanism of self-perpetuating injury to these residual units (5-8). We questioned whether compensatory changes in remnant tubular function with declining renal mass may prove injurious to the tubulo-interstitium.

Adaptive changes in ammonia production occur as functional renal mass is reduced (9). Studies in human and experimental renal disease demonstrate that, despite reductions in total ammonia production, ammonia excretion factored for glomerular filtration rate is increased severalfold (10-12). Ammonia production per surviving nephron more than doubles in rats with $70 \%$ reduction in renal mass (13). In addition, estimates of renal cortical partial pressure of ammonia based on direct measurement of intrarenal ammonia levels are elevated in rats with reduced renal mass on standard diets (14). Because ammonia has been implicated in the pathogenesis of both renal (15-17) and extrarenal tissue injury (18), we explored the role of ammonia in the pathogenesis of tubulointerstitial injury in the remnant model of chronic renal insufficiency.

\section{Methods}

Our investigation consisted of three studies, designated studies I, II, and III, all of which involved the use of the remnant model of chronic renal failure in the rat. This model was made by removal of the right kidney and segmental infarction of the left kidney under methohexithal anesthesia $(5 \mathrm{mg} / 100 \mathrm{~g}$ of body weight, i.p.). Serum creatinine was measured $3 \mathrm{~d}$ after nephrectomy on a Beckman Creatinine Analyzer 2, (Beckman Instruments, Inc., Fullerton, CA) from a tail vein blood sample. In studies I and II, animals were then paired into two groups based on serum creatinine, ensuring similar starting levels of renal function in both groups. In these studies, the diet of the experimental group was supplemented with sodium bicarbonate $\left(\mathrm{NaHCO}_{3}\right)$ to reduce dietary acid load and to suppress ammonia production. We calculated that $2.5 \mathrm{meq}$ of bicarbonate per $10 \mathrm{~g}$ of food intake of a $20 \%$ powdered protein diet (Teklad No. 170597, Teklad, Madison, WI) would exceed the daily nonvolatile acid production yielded by such a diet. The control group was maintained on an identical $20 \%$ powdered protein diet but supplemented instead with equimolar sodium chloride $(\mathrm{NaCl})$.

Study I was designed to compare the effect of dietary supplementation with $\mathrm{NaHCO}_{3}$ versus $\mathrm{NaCl}$ on the remnant kidney model 4-6 wk after $1 \frac{3}{4}$ nephrectomy, a time when indices of renal injury, both functional and morphologic, can be measured. Study II was performed to assess the role of glomerular hemodynamics in renal injury in rats supplemented with either $\mathrm{NaHCO}_{3}$ or $\mathrm{NaCl}$. Micropuncture studies were thus undertaken at $1 \frac{1}{2}-2$ wk after subtotal nephrectomy, before the occurrence of severe renal injury and heterogeneity of nephron function. Study III examined the acute effects of systemic alkalosis on renal function in subtotally nephrectomized animals. 
Study I: renal function, morphology and immunofluorescence 4-6 wk after subtotal nephrectomy

In vivo renal studies. Male rats, weighing 225-250 $\mathrm{g}$ and paired for serum creatinine after $1 \frac{3}{4}$ nephrectomy, were maintained for 4-6 wk on a $20 \%$ protein diet supplemented with either $\mathrm{NaHCO}_{3}$ (experimental group) or $\mathrm{NaCl}$ (control group). The animals had free access to food and water. At the end of the study period, the animals were housed separately in metabolic cages for $24 \mathrm{~h}$, during which time food and water intake was monitored and 24-h urine output was collected. Total urinary protein excretion was assayed by the sulfosalicyclic acid method in each animal. For quantitation of low molecular weight protein excretion over $24 \mathrm{~h}$, a urine sample from each of the animals was filtered on a PM-10 membrane in an Amicon ultrafiltration cell (Amicon Corp., Danvers, MA) to permit the passage of proteins with molecular weight $<10,000$. For each urine sample the fraction of the total urinary protein that comprised protein molecules $<10,000 \mathrm{~mol}$ wt was measured (19). Using this fraction, and the total urinary protein excretion per $24 \mathrm{~h}$ as determined by the sulfosalicyclic acid method the amount of low molecular weight $(<10,000 \mathrm{~mol} \mathrm{wt})$ protein excreted over $24 \mathrm{~h}$ was determined.

On the morning of clearance studies, animals underwent tracheostomy after Inactin anesthesia ( $100 \mathrm{mg} / \mathrm{kg}$ of body weight, i.p.). PE50 polyethylene catheters were inserted into both internal jugular veins for infusion. A PE-50 catheter was inserted into the left femoral artery for blood sampling and for blood pressure monitoring via a Statham pressure transducer (model P23Db, Statham Instruments, Oxnard, CA) connected to a Gilson Duograph recorder, (model ICT-2H, Gilson Medical Electronics, Inc., Middleton, WI). The left ureter was catheterized with PE-10 tubing and urine was collected under oil. To determine glomerular filtration rate (GFR), ${ }^{1}$ a solution of normal saline containing $\left[\right.$ methoxy $\left.{ }^{3} \mathrm{H}\right]$ inulin $(10 \mu \mathrm{Ci} / \mathrm{ml})$ was infused at a rate of $1.2 \mathrm{ml} / \mathrm{h}$ after a priming dose of $0.5 \mathrm{ml}$ over $5 \mathrm{~min}$. To assess transport maximum for para-aminohippurate, TmPAH, a $4 \%$ solution of para-aminohippurate (PAH) was infused at a rate of $1.2 \mathrm{ml} / \mathrm{h}$ after a priming dose of $0.5 \mathrm{ml}$ over $5 \mathrm{~min}$. After allowing $45 \mathrm{~min}$ for equilibration, two clearance collections were performed. Urine volume was measured in a calibrated glass tube. Hematocrit was determined by the Micro-Capillary Hematocrit Reader (International Equipment Co., Needham Heights, MA) and total plasma protein concentration by refractometry. Radioactivity in urine and plasma was determined by liquid scintillation counting. Plasma and urine concentrations of PAH were determined by the method of Smith et al. (20). GFR and TmPAH were calculated by standard formulas.

After the completion of clearance studies, a sample of renal vein blood was drawn for measurement of renal vein total ammonia concentration. After centrifugation at $4^{\circ} \mathrm{C}$, the plasma was frozen and analyzed for total ammonia concentration by the ion-exchange resin and Bertholet reaction method (21). A sample of aortic blood was immediately analyzed for arterial blood gases and derived bicarbonate by an Instrumentation Laboratory blood gas analyzer (Instrumentation Laboratory, Inc., Waltham, MA).

Remnant kidney tissue was divided for histology and immunofluorescence. Tissue for histopathology was fixed in glacial acetic acid Zenker's solution, sectioned at $5 \mu \mathrm{m}$, and stained with hematoxylin and eosin. Sections were examined in a coded blinded manner with regard to cast formation, dilatation of tubules, interstitial fibrosis and cellular infiltrate, and the extent of glomerular sclerosis. The largest external diameters were measured for 20 randomly selected tubules at the cortico-medullary junction. The number of intratubular casts at the cortico-medullary junction in a $2,500-\mu \mathrm{m}^{2}$ area were counted and the number of casts per 1,000 tubules was derived.

For immunofluorescent studies, remnant kidney tissue was first snap-frozen in isopentane in a dry ice/acetone bath. $4-\mu \mathrm{m}$ sections

1. Abbreviations used in this paper: GFR, glomerular filtration rate; SNGFR, single nephron glomerular filtration rate; TmPAH, transport maximum for para-aminohippurate. were cut on a cryostat at $-20^{\circ} \mathrm{C}$, fixed in acetone, and stained by a double antibody sandwich technique for C3, C5b-9, IgG, and albumin. Appropriate dilutions of IgG fractions of goat anti-rat C3, goat antirat IgG, and rabbit anti-rat albumin (Cappel Laboratories, Malvern, PA) were applied to tissue sections, incubated for $60 \mathrm{~min}$ at $20^{\circ} \mathrm{C}$ in a humidified chamber, and washed three times with phosphate-buffered saline. Secondary antibodies, applied in the same fashion, included fluorescein isothiocyanate conjugates of rabbit anti-goat IgG and goat anti-rabbit IgG (Cappel Laboratories). Rat C5b-9 was purified on BioGel A-15m (Bio-Rad Laboratories, Richmond, CA) as a macromolecular complex from detergent-solubilized membranes of IgG-sensitized sheep erythrocytes after hemolysis in rat serum, according to the method of Ware et al. (22). Antiserum to the C5b-9 complex was raised in rabbits after three immunizations with $0.2 \mathrm{mg}$ of protein complex in $0.5 \mathrm{ml}$ of complete Freund's adjuvant and was precipitated with caprylic acid to isolate the IgG fraction for use as a primary antibody in immunofluorescence.

In vitro complement studies. To assess the effects of ammonia on the formation of amidated $\mathrm{C} 3$ and its activity as an alternative pathway convertase, a standard assay for the hemolysis of rabbit erythrocytes by the alternative pathway was employed (23). 1.5-10 $\mu$ l of daily prepared stock solutions of $20 \mathrm{mM}$ or $1 \mathrm{M} \mathrm{NH} \mathrm{N}_{4} \mathrm{Cl}$ in distilled $\mathrm{H}_{2} \mathrm{O}$ was added to 200- $\mu$ l aliquots of normal human serum for final concentrations of $0.150,0.250,0.500,1.0$, and $10.0 \mathrm{mM} \mathrm{NH}_{4} \mathrm{Cl}$. After incubation at $37^{\circ} \mathrm{C}$ for $3 \mathrm{~h}$, control and amidated serum samples were diluted 1:20, 1:26.6, 1:40, and 1:50 with a standard solution of 0.0025 $M$ magnesium chloride, $0.075 \mathrm{M} \mathrm{NaCl}, 0.01 \mathrm{M}$ EGTA, $0.14 \mathrm{M}$ Dglucose, $0.1 \%$ gelatin, and $0.01 \mathrm{M}$ veronal $(\mathrm{pH} 7.5)$, held at $4^{\circ} \mathrm{C}$ for $15 \mathrm{~min}$ to chelate calcium, and incubated with $2.5 \times 10^{7}$ rabbit erythrocytes for $60 \mathrm{~min}$ in a $37^{\circ} \mathrm{C}$ water bath. At the end of the incubation period, $4.0 \mathrm{ml}$ of $0.15 \mathrm{M} \mathrm{NaCl}$ was added to each specimen, and the degree of hemolysis was assessed spectrophotometrically as the optical density at $414 \mathrm{~nm}$. For each experiment, hemolytic controls consisted of $200 \mu$ l of serum without $\mathrm{NH}_{4} \mathrm{Cl}$ (base-line control), buffer alone, and buffer with $\mathrm{NH}_{4} \mathrm{Cl}$ in concentrations ranging from 0.150 to $10 \mathrm{mM}$.

\section{Study II: glomerular function as assessed by micropuncture $1 \frac{1}{2}$ wk after subtotal nephrectomy}

Male Munich-Wistar rats, $1 \frac{2}{3}$ nephrectomized, weighing 210-325 g and paired into two groups on the basis of serum creatinine as described, were maintained on $\mathrm{NaHCO}_{3}$ - or $\mathrm{NaCl}$-supplemented $20 \%$ protein diets for $1 \frac{1}{2}-2$ wk. On the morning of micropuncture, rats were anesthetized with Inactin (100 mg/kg of body weight, i.p.), and were prepared for micropuncture. At the beginning of each experiment, an arterial blood sample was taken for the determination of background counts, hematocrit, and total protein. All animals were infused with isoncotic rat plasma equal to $1 \%$ of body weight to replace surgical losses and maintain constancy of initial hematocrit. To determine GFR and single nephron glomerular filtration rates (SNGFR), normal saline containing [ $m e t h o x y-{ }^{3} \mathrm{H}$ ]inulin $(100 \mu \mathrm{Ci} / \mathrm{ml})$ was infused at a rate of $1.2 \mathrm{ml} / \mathrm{h}$ after a priming dose of $0.5 \mathrm{ml}$ given over $5 \mathrm{~min}$. Timed samples of proximal tubular fluid were obtained by micropuncture from random proximal surface convolutions for determination of total radioactivity. To obtain renal venous samples, a 23-gauge needle connected to a tuberculin syringe by PE-50 tubing was inserted in the left renal vein. Filtration fraction was calculated from the extraction of inulin. Hydraulic pressure measurements were made in cortical tubules, cortical vessels, and glomerular capillaries of surface glomeruli by the servo-null micropipette technique. SNGFR, filtration fraction, initial glomerular capillary plasma flow rate $\left(Q_{\mathrm{A}}\right)$, and the mean transcapillary hydraulic pressure gradient $(\overline{\Delta P})$ were calculated by standard formulas.

\section{Study III: effect of systemic alkalosis on renal function in subtotally nephrectomized rats}

Subtotally nephrectomized male rats, weighing 250-275 g, were maintained on a $20 \%$ protein diet and water ad libitum for 2-3 wk. 
Determinations of GFR, TmPAH, and TmPAH/GFR were then performed by clearance techniques as described (see above, study I). After basal clearance determinations, a solution containing $125 \mathrm{mM}$ $\mathrm{NaHCO}_{3}$ and $15 \mathrm{mM} \mathrm{KHCO}$ was infused, at a rate of $\sim 5 \%$ body weight/hour for a duration of $20 \mathrm{~min}$. Clearance of inulin and PAH was repeated after the infusion. A sample of aortic blood was taken at the end of the last clearance period for determination of arterial blood gases and derived bicarbonate. Concentration of albumin in urine samples obtained during the clearance study was measured by rate nephelometry using the Beckman Immunochemistry Analyzer (Beckman Instruments, Inc.). Goat-derived anti-rat albumin (Cappel Laboratories) was used to generate the antigen-antibody reaction for this measurement.

\section{Study IV: effect of genetic deficiency of complement component $C 5$ on proteinuria in subtotally nephrectomized mice}

Mice sufficient (B10.D2NSN) and deficient (B10.D20SN) for the fifth component of complement (C5) were obtained from Jackson Laboratories (Bar Harbor, ME). Adult male mice of each strain were subjected to partial renal ablation by right nephrectomy and infarction of approximately one-third of the remaining kidney by ligation of the single segmental renal artery. The mice were allowed ad libitum access to the same diets. They were placed in metabolic cages before and at regular intervals after the ablative procedure. 24-h urines were collected for measurement of total protein as described above.

\section{Statistics}

Data are presented as means \pm standard errors. The Student's $t$ test was used to assess statistical significance; differences were considered statistically significant for $P<0.05$.

\section{Results}

Study I

In vivo renal studies. After 4-6 wk both $\mathrm{NaHCO}_{3}$ - and $\mathrm{NaCl}-$ supplemented rats appeared healthy. There was no difference in mean body weight, food intake over $24 \mathrm{~h}$, total plasma protein concentration, or hematocrit (Table I).

Total urinary protein excretion in $\mathrm{NaHCO}_{3}$-supplemented rats, $41 \pm 13 \mathrm{mg} / 24 \mathrm{~h}$, was almost half that of the $\mathrm{NaCl}$ supplemented rats, which was $74 \pm 16 \mathrm{mg} / 24 \mathrm{~h} \quad(P<0.05)$ (Table II). Similarly, urinary excretion of low molecular weight proteins (mol wt $<10,000$ ) in $\mathrm{NaHCO}_{3}$-supplemented rats, $14 \pm 3 \mathrm{mg} / 24 \mathrm{~h}$, was diminished by $50 \%$ as compared to $28 \pm 8$ $\mathrm{mg} / 24 \mathrm{~h}$, in $\mathrm{NaCl}$-supplemented rats $(P<0.02)$. Thus, protein excretion rates suggested less renal injury in $\mathrm{NaHCO}_{3}$-supplemented rats as compared to $\mathrm{NaCl}$-supplemented rats and the decreased urinary excretion of low molecular weight protein

Table I. General Parameters in Animals in Study I

\begin{tabular}{lcccc}
\hline & $\begin{array}{l}\text { No. of } \\
\text { pairs }\end{array}$ & $\begin{array}{l}\text { NaHCO }_{3} \\
\text { supplemented }\end{array}$ & $\begin{array}{l}\text { NaCl- } \\
\text { supplemented }\end{array}$ & $P$ \\
\hline & $n$ & & & \\
$\begin{array}{l}\text { Body weight, } g \\
\begin{array}{l}\text { Food intake/ } \\
24 \text { h, } g\end{array}\end{array}$ & 11 & $283 \pm 11.9$ & $287 \pm 9.6$ & NS \\
$\begin{array}{l}\text { Hematocrit } \\
\text { Total plasma } \\
\text { protein, } g / d l\end{array}$ & 11 & $11.4 \pm 1.5$ & $11.0 \pm 2.3$ & NS \\
& 8 & $42 \pm 1.7$ & $39.5 \pm 3.3$ & NS \\
\hline
\end{tabular}

Table II. Renal Function in Animals in Study I

\begin{tabular}{llcll}
\hline & $\begin{array}{l}\text { No. of } \\
\text { pairs }\end{array}$ & $\begin{array}{l}\mathrm{NaHCO}_{3} \\
\text { supplemented }\end{array}$ & $\begin{array}{l}\text { NaCl- } \\
\text { supplemented }\end{array}$ & $P$ \\
\hline & $n$ & & & \\
Urinary total protein & & & & \\
excretion, $m g / 24 h$ & 8 & $41 \pm 13$ & $74 \pm 16$ & $<0.05$ \\
$\begin{array}{l}\text { Urinary low } \\
\text { molecular weight }\end{array}$ & & & & \\
protein $(\leqslant 10,000$ & & & & \\
mol wt) excretion, & & $14 \pm 3$ & $28 \pm 8$ & $<0.02$ \\
mg/24 $h$ & 8 & $0.45 \pm 0.07$ & $0.47 \pm 0.09$ & NS \\
GFR, $m l /$ min & 7 & $113 \pm 24$ & $73 \pm 16$ & NS \\
TmPAH, $\mu g /$ min & 7 & $250 \pm 30$ & $140 \pm 30$ & $<0.05$ \\
TmPAH/GFR, $\mu g / m l$ & 7 & & & \\
\hline
\end{tabular}

suggested preservation in tubular functional capacity to reabsorb low molecular weight proteins. There was no difference in GFR in $\mathrm{NaHCO}_{3}$ - versus $\mathrm{NaCl}$-supplemented rats. TmPAH in $\mathrm{NaHCO}_{3}$-supplemented rats, $113 \pm 24 \mu \mathrm{g} / \mathrm{min}$, was higher than in $\mathrm{NaCl}$-supplemented rats, $73 \pm 16 \mu \mathrm{g} / \mathrm{min}$, although this difference did not attain statistical significance. However, TmPAH/GFR in $\mathrm{NaHCO}_{3}$ rats, $250 \pm 30 \mu \mathrm{g} / \mathrm{ml}$, was significantly higher $(P<0.05)$ than in $\mathrm{NaCl}$ rats, measured at $140 \pm 30 \mu \mathrm{g} / \mathrm{ml}$. Hence, per unit glomerular filtration rate, $\mathrm{NaHCO}_{3}$-supplemented rats demonstrated greater ability to secrete PAH.

Plasma chemistries demonstrated a statistically higher plasma bicarbonate concentration in $\mathrm{NaHCO}_{3}$-supplemented rats, $31 \pm 0.7 \mathrm{meq} / \mathrm{liter}$, as compared to $\mathrm{NaCl}$-supplemented rats, $20.4 \pm 1.6 \mathrm{meq} / \mathrm{liter}(P<0.01)$. Mean renal vein total ammonia concentration in $\mathrm{NaHCO}_{3}$-supplemented rats, $145 \pm 20 \mu \mathrm{M}$, was lower than in $\mathrm{NaCl}$ rats, $240 \pm 20 \mu \mathrm{M}(P$ $<0.05$ ). Thus, supplementation of the $20 \%$ protein diet with $\mathrm{NaHCO}_{3}$ achieved a lower renal vein ammonia concentration in conjunction with systemic alkalinization.

Analysis by light microscopy demonstrated fewer intratubular casts in $\mathrm{NaHCO}_{3}$ rats, measured at $5 \pm 2$ casts per 1,000 tubules at the corticomedullary junction as compared to $23 \pm 8$ intratubular casts per 1,000 tubules in $\mathrm{NaCl}$-supplemented rats $(P<0.05)$. Moreover, interstitial infiltration and tubular dilation and atrophy were less pronounced in $\mathrm{NaHCO}_{3}$-supplemented rats as compared to $\mathrm{NaCl}$ rats (Fig. 1). Mean external tubular diameter, was $35 \pm 3.2 \mu \mathrm{m}$ in $\mathrm{NaHCO}_{3}$-supplemented rats and $42 \pm 3.8 \mu \mathrm{m}$ in $\mathrm{NaCl}$-supplemented rats $(0.05<P<0.1)$. Hence, less severe histologic evidence of tubulo-interstitial injury occurred in conjunction with less damage to tubular transport functions of organic anion secretion and protein reabsorption in rats with lower renal venous levels of ammonia.

Immunofluorescent studies demonstrated markedly different patterns in the remnant kidney of $\mathrm{NaCl}$-supplemented versus $\mathrm{NaHCO}_{3}$-supplemented rats (Fig. 2). In $\mathrm{NaCl}$-supplemented rats, there was widespread circumferential fluorescence for C3, whereas in $\mathrm{NaHCO}_{3}$-supplemented rats, peritubular immunofluorescence was much reduced. C5b-9 was also found to be diffusely deposited in a more granular but circumferential peritubular pattern in $\mathrm{NaCl}$ rats, whereas in the $\mathrm{NaHCO}_{3}^{-}$ supplemented rats there was again marked diminution of such deposition. Peritubular immunofluorescence for IgG and albumin was absent for all rats of both groups. Thus, the peritubular deposition of complement components appears 

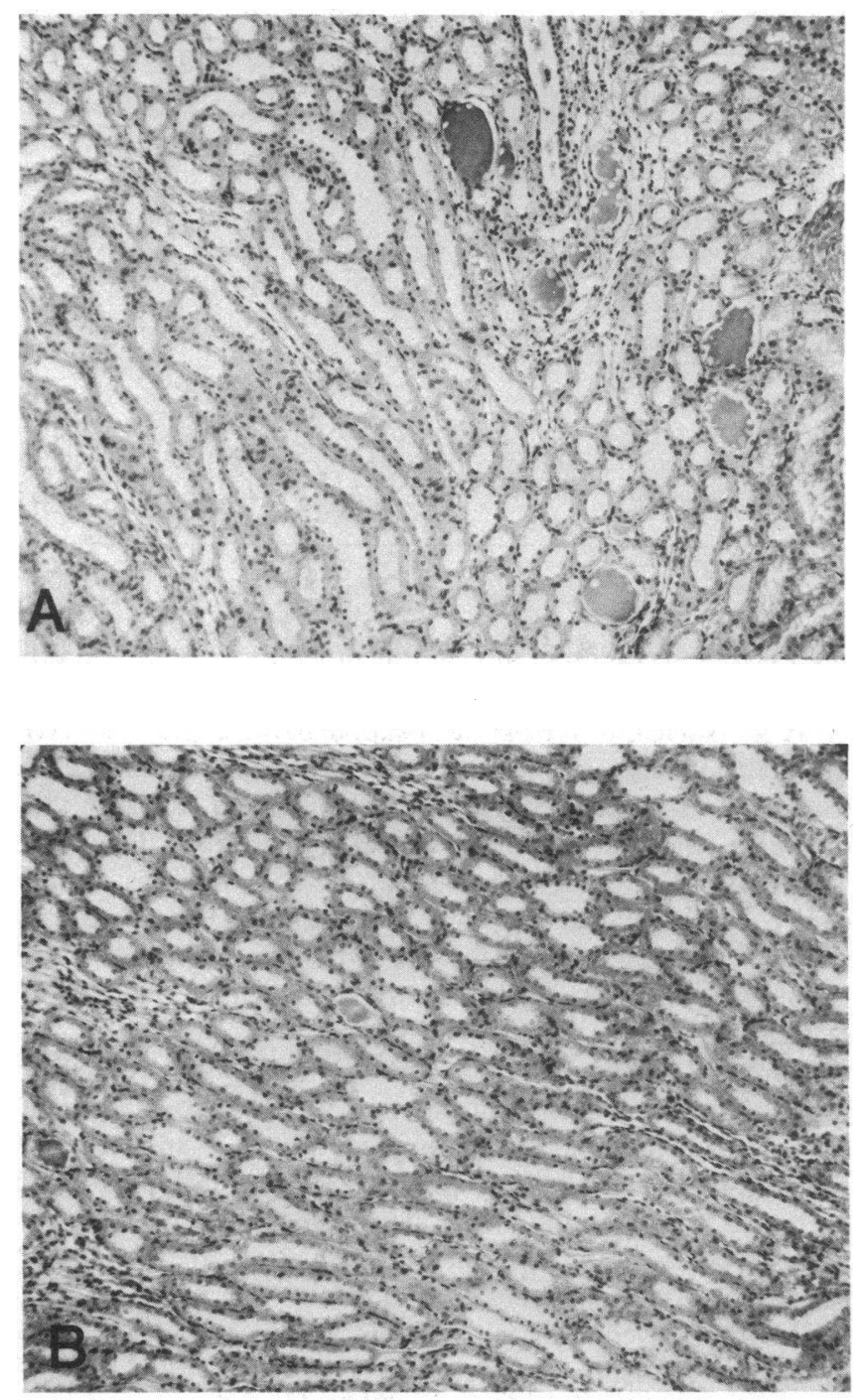

Figure 1. Sections of the remnant kidney at the cortico-medullary junction examined by light microscopy at $\times 120$ from $\mathrm{NaCl}$-supplemented $(A)$ and $\mathrm{NaHCO}_{3}$-supplemented $(B)$ rats. $\mathrm{NaHCO}_{3}$-supplemented rats have fewer intratubular casts, less tubular dilation, and less interstitial fibrosis.

unique and is not the consequence of nonspecific deposition of macromolecules.

In vitro complement studies. Titration of hemolytic activity in control samples and in samples containing increasing concentrations of $\mathrm{NH}_{4} \mathrm{Cl}$ (range $0.150-10 \mathrm{mM}$ ) revealed a biphasic effect of the presence of ammonia on the hemolytic activity of normal human serum (Fig. 3). In comparison to the control samples, the presence of $0.150 \mathrm{mM} \mathrm{NH}_{4} \mathrm{Cl}$ in serum led to a tendency to increased hemolytic activity over baseline, whereas $0.250 \mathrm{mM} \mathrm{NH}_{4} \mathrm{Cl}$ caused an even greater increase in hemolytic activity $(P<0.05)$. No hemolysis was observed when rabbit erythrocytes were incubated with $0.150-10 \mathrm{mM} \mathrm{NH}_{4} \mathrm{Cl}$ in the absence of serum.

At concentrations $>0.500 \mathrm{mM} \mathrm{NH}_{4} \mathrm{Cl}$, however, hemolytic activity of amidated serum samples fell below that of control samples and was significantly different from base-line values at concentrations of 1.0 and $10 \mathrm{mM} \mathrm{NH}_{4} \mathrm{Cl}(P<0.05$ and 0.001 , respectively).

\section{Study II}

Micropuncture studies were performed $1 \frac{1}{2}-2$ wk after subtotal nephrectomy. Results are summarized in Table III. Both $\mathrm{NaHCO}_{3}$ - and $\mathrm{NaCl}$-supplemented rats had comparable body weights, total plasma protein concentrations, hematocrits, mean arterial pressures, and GFR. Glomerular hemodynamics were remarkably similar in that there was no statistical difference in SNGFR, $\overline{Q_{\mathrm{A}}}$, and $\overline{\Delta P}$ (Table III). Thus, although there was evidence of glomerular hyperfiltration and hyperperfusion in both the $\mathrm{NaHCO}_{3}$ - and $\mathrm{NaCl}$-supplemented rats, the extent to which glomerular pressures and flows were augmented was not different in these two groups.

\section{Study III}

Results are summarized in Table IV. Mean plasma bicarbonate concentration achieved after $\mathrm{NaHCO}_{3}$-supplemented infusion was $38 \pm 3 \mathrm{meq} / \mathrm{liter}$. There was no statistical difference in basal rates of albumin excretion and basal TmPAH/GFR as compared to values for these parameters after plasma bicarbonate levels were elevated (Table IV). Thus differences in rates of protein excretion and tubular function as assessed by TmPAH/ GFR are not attributed simply to systemic alkalinization or to elevation of plasma bicarbonate concentration.

\section{Study IV}

Mice sufficient or deficient for the fifth component of complement were studied by measurements of 24-h excretion of total protein before and after subtotal nephrectomy. As demonstrated in Table V, animals with deficiency of the fifth component of complement, had a tendency to lower protein excretions even before nephrectomy, however, this difference was not of statistical significance. For the first 20 wk after subtotal nephrectomy, this tendency for slightly greater proteinuria persisted though the rate did not change within either sufficient or deficient groups. At the 30th week after partial renal ablation, both groups demonstrated increased protein excretion and to a substantially greater degree in the sufficient animals.

\section{Discussion}

With chronic progressive renal disease, structural abnormalities increasingly envelop the tubulo-interstitial and glomerular compartments of the kidney $(1,2)$. The process culminates in the typical architectural disarray of the end-stage kidney in which the interstitium is invaded by cellular infiltration and fibrosis; tubules become atrophic and dilated and are frequently filled with casts; and glomeruli are transformed into partially or totally sclerosed tufts $(1,2)$. Such structural changes are of functional significance for both glomerular and tubulo-interstitial diseases; histologic evidence of tubulo-interstitial abnormalities correlates closely with the decline in such indices of renal function as GFR, renal plasma flow, concentrating ability, and the ability to maximally acidify the urine $(1,2$, 24, 25).

With loss of renal mass, tubular adaptation in the handling of solutes and water occurs. Our study focuses on the adaptive changes in acid excretion in general and ammonia production in particular. In human and experimental chronic renal disease, total urinary ammonium excretion decreases $(10,11)$. However, when corrected for GFR, ammonium excretion increases several fold above control values $(10-12)$. Studies in rats subjected to $70 \%$ reduction of renal mass have demonstrated that ammo- 

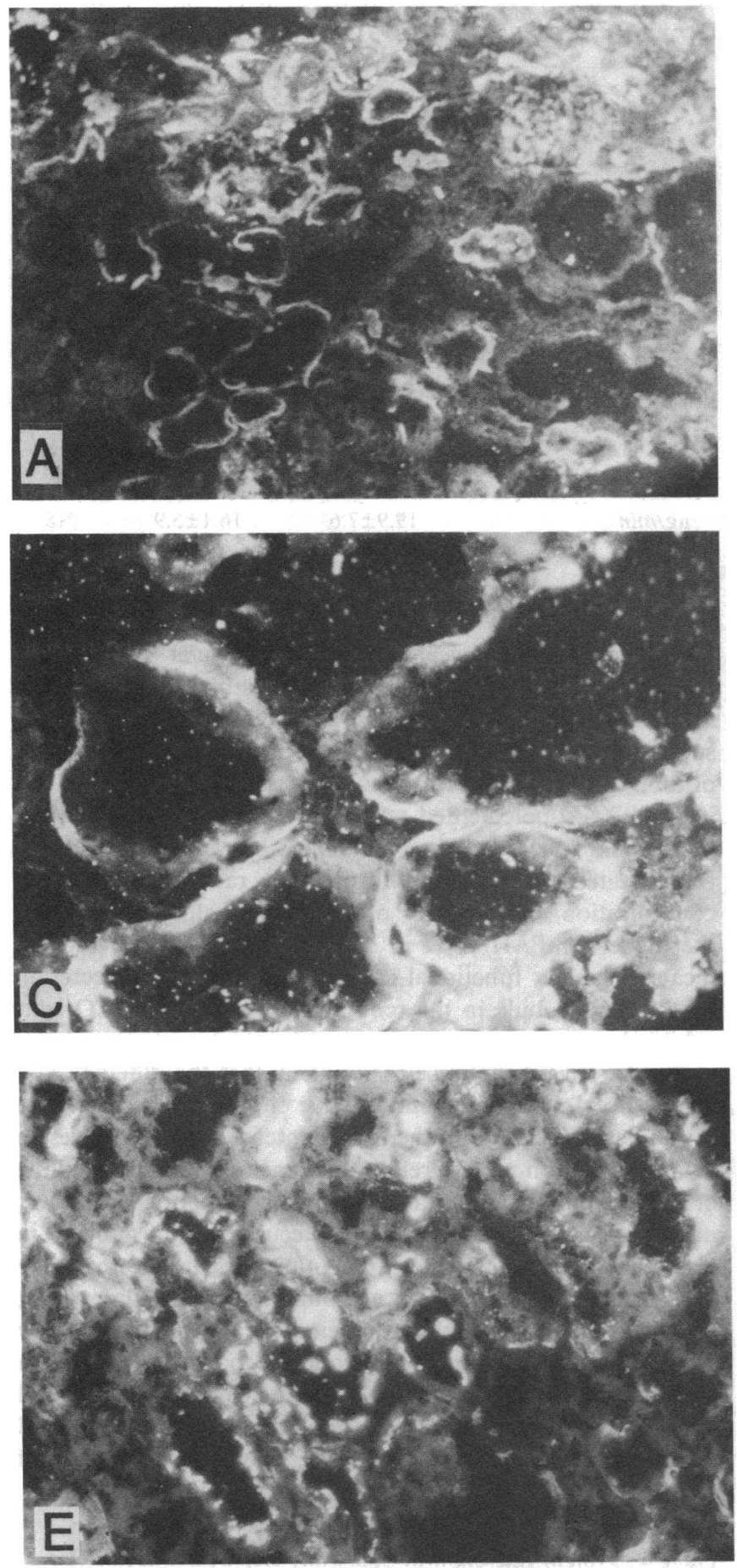

Figure 2. Sections of the remnant kidney examined by immunofluorescence for complement proteins $\mathrm{C} 3$ and $\mathrm{C} 5 \mathrm{~b}-9$. NaCl-supplemented rats $(A, C, E)$ display circumferential peritubular staining for $\mathrm{C} 3$ at

nium production per nephron more than doubles (13), a finding corroborated by the demonstration of increased ammonia production from its major metabolic source, glutamine, by renal cortical slices taken from the remnant kidney (12). Thus adaptive increments in ammonia production occur with reduced renal mass. Micropuncture analysis in the remnant kidney has localized this increased production principally to the proximal tubule (14), the same site where the bulk of
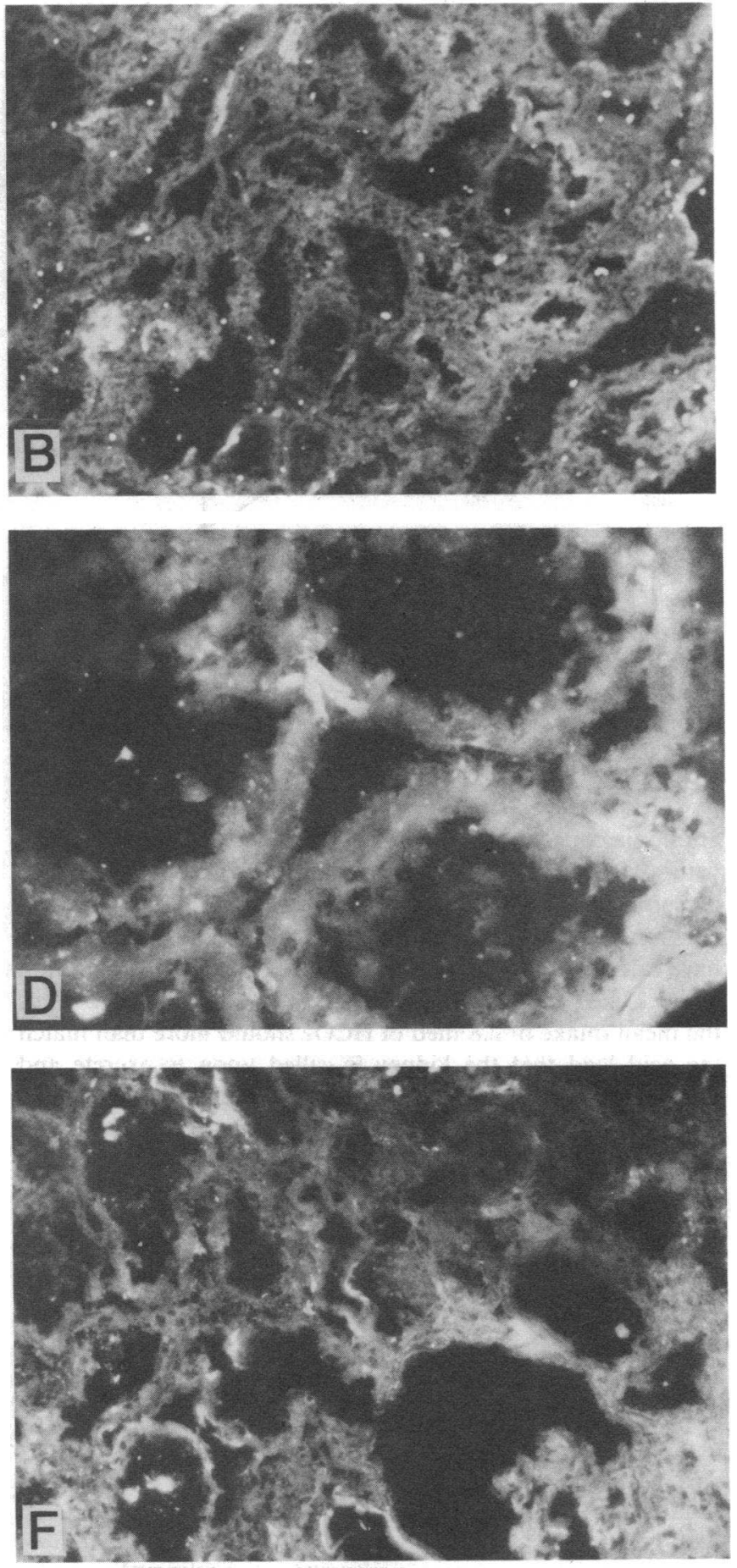

$\times 100(A)$, for $\mathrm{C} 3$ at $\times 400(C)$, and for C5b-9 at $\times 100(E)$, whereas immunofluorescence for these proteins is much reduced in the $\mathrm{NaHCO}_{3}$-supplemented animals $(B, D, F$, respectively).

ammonia production occurs in the normal animal (26). In addition, calculation of renal cortical levels of ammonia has revealed significant elevations in the cortex of the remnant kidney (14), presumably the result of augmented ammoniagenesis out of proportion to rates of removal.

Our data demonstrate that in $\mathrm{NaHCO}_{3}$-supplemented rats, with a mean $\mathrm{HCO}_{3}^{-}$intake per day of $2.8 \mathrm{meq}$, the plasma $\mathrm{HCO}_{3}^{-}$was significantly elevated and the renal venous total 


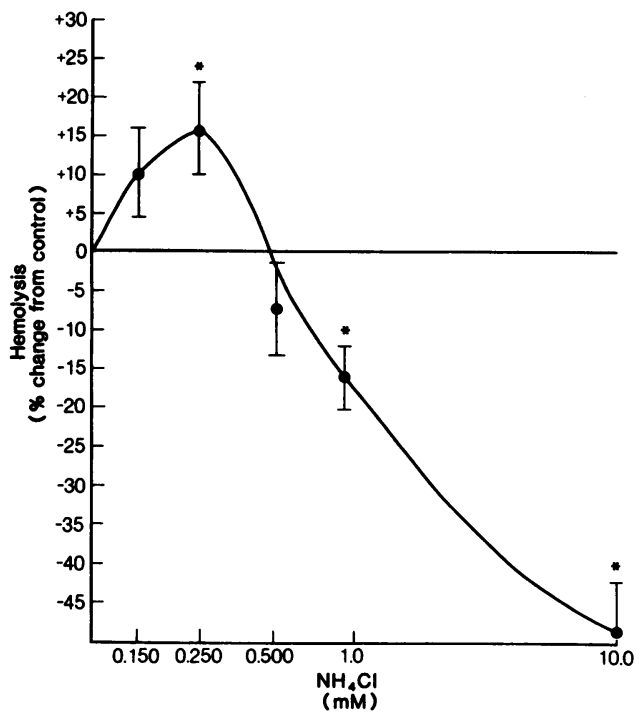

Figure 3. Hemolytic activity in serum samples diluted 1:40 and containing $0.150-10 \mathrm{mM} \mathrm{NH}_{4} \mathrm{Cl}$. Hemolysis observed in a 1:40 dilution of serum without $\mathrm{NH}_{4} \mathrm{Cl}$ serves as base-line control (horizontal line). Each point represents the mean \pm SE for eight experiments.

${ }^{*} P<0.05$ vs. base-line control value.

ammonia concentration was significantly reduced from control values. Systemic alkalinization was sustained in these rats presumably because of the reduction in GFR induced by ablation (27). Based on the data of Schoolwerth et al. (12), we have calculated that rats would excrete $\sim 1$ meq of ammonium and 1.3 meq total acid per day on a $20 \%$ protein diet. Thus the mean intake of 2.8 meq of $\mathrm{HCO}_{3}^{-}$should more than match the acid load that the kidney is called upon to excrete and thereby lead to net negative acid loads. The finding of systemic alkalosis is consistent with this calculation. By buffering the dietary acid load, bicarbonate supplementation would be expected to diminish the adaptive increases in ammonia production, and thereby decrease the tissue levels of ammonia. In $\mathrm{NaHCO}_{3}$-supplemented rats, renal cortical ammonia levels, as indicated by renal vein total ammonia concentration (28), were reduced.

$\mathrm{NaHCO}_{3}$-supplemented rats also exhibit less tubule-interstitial disease as demonstrated by three lines of evidence. (a)

Table III. Glomerular Hemodynamics in Study II

\begin{tabular}{lccc}
\hline & $\begin{array}{l}\mathrm{NaHCO}_{3-} \\
\text { supplemented } \\
n=5\end{array}$ & $\begin{array}{l}\text { NaCl- } \\
\text { supplemented } \\
n=6\end{array}$ & $P$ \\
\hline Body weight, $g$ & $278 \pm 13$ & $295 \pm 6$ & NS \\
Total plasma protein, $g / d l$ & $6.2 \pm 0.2$ & $6.3 \pm 0.2$ & NS \\
Hematocrit & $43 \pm 3.4$ & $47 \pm 1.4$ & NS \\
Mean arterial pressure, & & & \\
$\quad$ mmHg & $110 \pm 7$ & $110 \pm 3$ & NS \\
GFR, $\mathrm{ml} / \mathrm{min}$ & $0.65 \pm 0.09$ & $0.72 \pm 0.06$ & NS \\
Filtration fraction & $0.26 \pm 0.03$ & $0.26 \pm 0.01$ & NS \\
SNGFR, $n l / m i n$ & $63.5 \pm 8.3$ & $61.4 \pm 8.1$ & NS \\
$Q_{\mathrm{A}}, \mathrm{nl} / \mathrm{min}$ & $291.1 \pm 90.6$ & $240.2 \pm 34.4$ & $\mathrm{NS}$ \\
$\Delta P, \mathrm{mmHg}$ & $37.0 \pm 3.0$ & $38.0 \pm 1.0$ & $\mathrm{NS}$ \\
& & & \\
\hline
\end{tabular}

Table IV. Effect of Infusion of $\mathrm{HCO}_{3}^{-}$in Subtotally Nephrectomized Rats in Study III

\begin{tabular}{|c|c|c|c|}
\hline & $\begin{array}{l}\text { Before } \mathrm{HCO}_{3}^{-} \\
\text {infusion } \\
n=7\end{array}$ & $\begin{array}{l}\text { After } \mathrm{HCO}_{3}^{-} \\
\text {infusion } \\
n=7\end{array}$ & $P$ \\
\hline \multicolumn{2}{|c|}{ Mean arterial pressure, } & & NS \\
\hline Hematocrit & $49 \pm 1$ & $46 \pm 1$ & $<0.02$ \\
\hline $\begin{array}{l}\text { Total plasma prote } \\
\text { g/dl }\end{array}$ & $5.8 \pm 0.2$ & $5.3 \pm 0.3$ & NS \\
\hline GFR, $\mathrm{ml} / \mathrm{min}$ & $0.79 \pm 0.4$ & $0.81 \pm 0.05$ & NS \\
\hline $\begin{array}{l}\text { TmPAH, } \mu g / m l \\
\text { TmPAH/GFR, } \mu g\end{array}$ & $201 \pm 16$ & $197 \pm 18$ & NS \\
\hline $\begin{array}{l}\quad \min \\
\text { Albumin excretion }\end{array}$ & $256 \pm 14$ & $230 \pm 11$ & NS \\
\hline$\mu g / \min$ & $19.9 \pm 7.6$ & $16.1 \pm 5.9$ & NS \\
\hline
\end{tabular}

Histologic analysis revealed fewer intratubular casts at the cortico-medullary junction, reduced interstitial infiltration and fibrosis, and less tubular atrophy and dilatation in $\mathrm{NaHCO}_{3}$ supplemented rats. (b) TmPAH/GFR, a widely used marker of tubular function in health and disease $(29,30)$, is increased in $\mathrm{NaHCO}_{3}$-supplemented rats. Such an increase in TmPAHGFR cannot be ascribed to differences between $\mathrm{NaHCO}_{3}$ and $\mathrm{NaCl}$-treated rats in terms of urinary flow rates, plasma protein concentration, or the effect of systemic alkalinization. Thus, the higher TmPAH/GFR in $\mathrm{NaHCO}_{3}$-supplemented rats indicates a greater functional capacity for organic ion secretion by the renal tubule in the remnant kidney. (c) $\mathrm{NaHCO}_{3}$ rats exhibit less urinary excretory rates for total protein and low molecular weight protein. It is unlikely that the differences in urinary total protein excretion derive entirely from differences in glomerular injury. Rather, we contend that differences in urinary excretion protein reflect differences in tubular handling of filtered protein, a contention directly supported by lower urinary excretion rates of low molecular weight protein in $\mathrm{NaHCO}_{3}$ rats. Tubulo-interstitial injury impairs the capacity of the proximal tubule to catabolize low molecular weight protein, either by intraluminal enzymic degradation or by endocytosis, thus allowing these molecules to escape degradation and be excreted in the urine. Thus, the finding of decreased urinary excretion rate of low molecular weight and total protein in $\mathrm{NaHCO}_{3}$ rats indicates greater preservation of

Table V. Protein Excretion in Subtotally Nephrectomized Mice Sufficient or Deficient in Complement Component C5

\begin{tabular}{ccccc}
\hline \multicolumn{5}{c}{ Duration of reduced renal mass, wk } \\
\cline { 2 - 5 } & 0 & 10 & 20 & 30 \\
\hline $\begin{array}{c}\text { Sufficient } \\
(n=7)\end{array}$ & 5.65 & 4.07 & 6.97 & $18.18^{*} \ddagger$ \\
Deficient & \pm 1.24 & 0.96 & 1.25 & 3.78 \\
$(n=6)$ & 2.76 & 1.84 & 3.90 & $6.33 \ddagger$ \\
& \pm 0.68 & 0.15 & 1.11 & 1.13 \\
$* P<0.05$ vs. deficient. & & & \\
$\ddagger P<0.05$ vs. 0 wk. & & & \\
\hline
\end{tabular}


tubular function of protein reabsorption and/or degradation. In addition, micropuncture studies performed $10-14 \mathrm{~d}$ postablation revealed that glomerular pressures and flows were augmented to the same degree in $\mathrm{NaHCO}_{3}$ - and $\mathrm{NaCl}$-treated rats. Thus, the severity of glomerular damage, sustained on a hemodynamic basis, predictably, should be similar in both groups.

We propose that ammonia reacts biochemically with the third component of complement to promote tubulo-interstitial injury. Peritubular deposition of complement proteins has been observed in a wide variety of chronic human renal disease, both nephritic and nonnephritic (31). As demonstrated in several experimental models of glomerulonephritis, antigenantibody complexes at the glomerular basement membrane trigger the classical complement pathway, and its component proteins, including C3 and C5b-9, are deposited in the glomerulus $(32,33)$. For nonnephritic diseases, antigen-antibody complexes that activate the classical pathway are not present, and the mechanism by which complement proteins are deposited about the tubules is unknown (31).

The remnant kidney in the rat provides one such model of nonnephritic renal disease (6). Evidence implicating the classic agents of immune renal injury, such as antibasement membrane antibody, is lacking $(8,34)$. However, our studies in the subtotally nephrectomized rat, chronically maintained on an $\mathrm{NaCl}$-supplemented diet, demonstrate a pattern of peritubular deposition of complement components similar to that described by Falk et al. (31) in a variety of human renal diseases. In our model, this peritubular deposition of both $\mathrm{C3}$ and $\mathrm{C} 5 \mathrm{~b}-9$ is diminished by $\mathrm{NaHCO}_{3}$ supplementation. Neither IgG nor albumin is observed in the peritubular area in either group of animals. Thus the difference in peritubular deposition of complement is not a consequence of nonspecific trapping of macromolecules. The marked reduction in the amount of C3 deposited in $\mathrm{NaHCO}_{3}$-treated rats is also associated with decreased tubulo-interstitial injury and lower renal cortical levels of ammonia.

The availability of animals with a single genetic defect resulting in the absence of the fifth component of complement allows a test of the role of the terminal complement components in the injury sustained by the remnant nephrons. Our studies indicate that the generation of the terminal cascade, the membrane attack complex, is important in the development of proteinuria in this model of chronic renal insufficiency. Although these studies do not distinguish between glomerular and tubulo-interstitial disease engendered by terminal complement components, they do support the view that in this model the presence of an intact terminal complement pathway is important in the resultant net renal injury.

We propose that lowering the renal cortical ammonia level leads to diminished deposition of $\mathrm{C} 3$ by reducing the reaction of ammonia with the reactive thiolester bond of $\mathrm{C} 3$. Interestingly, 25 yr ago, Beeson and Rowley (35) described an "anticomplementary effect of kidney tissue" in a rat model of coliform pyelonephritis and presented evidence that ammonia produced in the kidney attacked plasma complement proteins. More recently, the biochemistry of this reaction has been rigorously explored in vitro (36-38).

The molecular structure of $\mathrm{C} 3$ consists of two polypeptide chains, $\alpha$ and $\beta$. A conserved sequence of seven amino acids in the chain-Gly-Cys-Gly-Glu-Glu-Asn-Met-forms a macrocyclic ring in which resides the reactive thiolester bond of $\mathrm{C} 3$.
Nucleophilic amines, such as ammonia, attack the thiolester directly, breaking the bond and forming an amide linkage at the glutamyl carbonyl (37). This reaction is stoichiometric and specific only for the second glutamyl carbonyl: the amidated thiolester peptide has been sequenced for confirmation (39).

The modification of $\mathrm{C} 3$ by nucleophiles such as methylamine confers $\mathrm{C} 3 \mathrm{~b}$-like properties including the ability to form the alternative pathway convertase $(40-42)$. To assess the effects of free-base ammonia on the formation of amidated C3 and its activity as an alternative pathway convertase, we compared hemolytic activity of normal human serum with that of serum samples containing increasing concentrations of $\mathrm{NH}_{4} \mathrm{Cl}$ (range $0.150-10 \mathrm{mM}$ ) by using a standard assay for the hemolysis of rabbit erythrocytes by the alternative pathway (Fig. 3).

It was not surprising that concentrations of $\mathrm{NH}_{4} \mathrm{Cl}>1$ $\mathrm{mM}$ depressed the hemolytic activity of normal serum. Tack and colleagues (37) were the first to observe that $10 \mathrm{mM}$ methylamine reduced by $50 \%$ the hemolytic activity of human C3, and these experiments were subsequently confirmed with other nucleophiles $(38,39)$. Thus in our assay at concentrations of $\mathrm{NH}_{4} \mathrm{Cl}>1 \mathrm{mM}$, the accelerated formation of the enzymatic convertase (amidated C3) depletes its substrate (native C3) which alone is hemolytically active.

We, however, are the first to observe the stimulation of alternative pathway activity at lower concentrations, a range not studied in earlier papers. The physiologic importance of our observations is that, at the concentrations of ammonia measured in the kidneys of the experimental animals, the activity of the alternative pathway is amplified beyond that observed in the absence of ammonia. Amidated C3 thus forms the $\mathrm{C} 3 / \mathrm{C} 5$ convertase of the alternative pathway and cleaves both unreacted $\mathrm{C} 3$, which can then bind directly to carbohydrates or amino groups on cell surfaces $(39,43)$ as well as $C 5$, generating the chemoattractant $\mathrm{C} 5 \mathrm{a}$ and triggering the assembly of the membrane attack complex, C5b-9. Moreover, we have recently shown that amidated $C 3$ binds to the $C R 1$ receptor of polymorphonuclear leukocytes and monocytes and stimulates phagocytic oxidative metabolism (42). Thus, the rise in intrarenal ammonia concentration engendered by the adaptation to chronic renal disease determines attendant immunologic effects. Because ammonia reacts directly with $\mathrm{C} 3$ while in the fluid phase $(39,44)$, the formation of amidated $C 3$ is sufficient in itself to trigger the alternative complement pathway, to mediate the peritubular deposition of C3 and C5b-9, and to generate multiple molecular mediators of tissue injury.

While our data and hypothesis focus on complementmediated tubulo-interstitial injury and the degree to which it is influenced by ambient ammonia levels, other changes occurring with systemic alkalinization may underlie some of the structural and functional differences between $\mathrm{NaHCO}_{3}$ and $\mathrm{NaCl}$ rats. A higher urinary $\mathrm{pH}$ in conjunction with less proteinuria might inhibit intratubular cast formation, which in turn may diminish tubular injury. Also, the role of hyperbicarbonatemia per se in protecting remnant nephron against functional and structural injury is unknown. We demonstrate, however, that augmented $\mathrm{PAH}$ transport in $\mathrm{NaHCO}_{3}$-treated rats is not simply a consequence of systemic alkalosis, in that acute alkalinization failed to significantly raise TmPAH/GFR. However, it is conceivable that other chronic effects of alkalinization may have contributed to these results. Finally, our concern that systemic alkalinization may induce greater negative 
charge on circulating plasma protein and/or the glomerular filtration barrier and thereby reduce the degree of proteinuria, led us to study the effect of acute systemic alkalinization on protein excretion in the remnant rat kidney $(45,46)$. Again, no significant differences occurred in albumin excretory rates. We suspect that the lack of effect of acute alkalinization in remnant kidneys may be due to the overriding influence of already established size and charge permselective defects in remnant glomeruli (8). Furthermore, the differences in excretory rate of low molecular weight proteins argues for a difference in tubular absorption. However, the extent to which charge permselective defects in remnant glomeruli might also be improved by chronic alkalinization remains uncertain.

Our studies on dietary supplementation with $\mathrm{NaHCO}_{3}$ in rats with remnant kidneys demonstrate lower tissue levels of ammonia, less deposition of complement components and a diminution of tubulo-interstitial damage, both functionally as well as structurally. On the basis of these findings, we propose the following mechanism for ongoing tubulo-interstitial injury in the progression of chronic renal disease. First, tubular hyperfunction occurs in response to a reduction in renal mass. In remnant nephrons increased ammoniagenesis then supervenes, with increased renal concentration of ammonia. Local toxic and inflammatory effects of ammonia include the triggering of the alternative complement pathway by the reaction of ammonia with the $\mathrm{C} 3$ thiolester, culminating in the deposition of complement proteins and in the initiation of complement-mediated cellular infiltration and tissue injury. Tubular function is thereby further impaired, fueling a self-perpetuating cycle of adaptation and injury.

\section{Acknowledgments}

We thank R. A. Krueger, L. F. Mares, and S. F. Kren for technical assistance and $A$. Bont and $R$. Suek for typing the manuscript.

This work was supported by grants from the U. S. Public Health Service, AM-31437 (Dr. T. H. Hostetter) and AI-20716, and a Basil O'Connor Grant from the National Foundation March of Dimes (Dr. M. K. Hostetter). Dr. M. K. Hostetter is a recipient of a John A. and George L. Hartford Fellowship. Dr. K. A. Nath is a recipient of an Individual National Research Service Award of the U. S. Public Health Service.

\section{References}

1. Schainuck, L. I., G. E. Striker, R. E. Cutler, and E. P. Benditt. 1970. Structural-functional correlations in renal disease. II. The correlations. Hum. Pathol. 1:631-641.

2. Bohle, A., H. Christ, K. E. Grund, and S. Mackensen. 1979. The role of the interstitium of the renal cortex in renal disease. Contr. Nephrol. 16:109-114.

3. Chanutin, A., and S. Ludewig. 1936. Experimental renal insufficiency produced by partial nephrectomy. V. Diets containing whole dried meat. Arch. Int. Med. 58:60-80.

4. Morrison, A. B. 1962. Experimentally induced chronic renal insufficiency in the rat. Lab. Invest. 11:321-332.

5. Hostetter, T. H., J. L. Olson, H. G. Rennke, M. A. Venkatachalam, and B. M. Brenner. 1981. Hyperfiltration in remnant nephrons: a potentially adverse response to renal ablation. Am. J. Physiol. 241: F85-F93.

6. Hostetter, T. H., and B. M. Brenner. 1981. Glomerular adaptations to renal injury. In Contemporary Issues in Nephrology, Vol. 7: Chronic
Renal Failure. B. M. Brenner and J. H. Stein, editors. ChurchillLivingstone, New York. 1-27.

7. Brenner, B. M., T. W. Meyer, and T. H. Hostetter. 1982. Dietary protein and the progressive nature of kidney disease: The role of hemodynamically mediated glomerular injury in the pathogenesis of progressive glomerular sclerosis in aging, renal ablation, and intrinsic renal disease. $N$. Engl. J. Med. 307:652-659.

8. Olson, J. L., T. H. Hostetter, H. G. Rennke, B. M. Brenner, and M. A. Venkatachalam. 1982. Altered change-and-size selective properties of the glomerular wall: a response to reduced renal mass. Kidney Int. 22:112-126.

9. Hayslett, J. P. 1979. Functional adaptation to reduction in renal mass. Physiol. Rev. 59:137-164.

10. Simpson, D. P. 1971. Control of hydrogen ion homeostasis and renal acidosis. Medicine (Baltimore). 50:503-541.

11. Dorhout-Mees, E. J., M. Machado, E. Slatopolsky, S. Klahr, and N. S. Bricker. 1966. The functional adaptation of the diseased kidney. III. Ammonium excretion. J. Clin. Invest. 45:289-296.

12. Schoolwerth, A. C., R. S. Sandler, P. M. Hoffman, and S. Klahr. 1975. Effects of nephron reduction and dietary protein content on renal ammoniagenesis in the rat. Kidney Int. 7:397-404.

13. Maclean, A. J., and J. P. Hayslett. 1980. Adaptive change in ammonia excretion in renal insufficiency. Kidney Int. 17:595-606.

14. Buerkert, J., D. Martin, D. Trigg, and E. Simon. 1983. Effect of reduced renal mass on ammonium handling and net acid formation by the superficial and juxtamedullary nephrons of the rat. J. Clin. Invest. 71:1661-1675.

15. Wickham, J. E. A., and G. P. Sharma. 1965. Endogenous ammonia formation in experimental renal ischaemia. Lancet. 1:195198.

16. Preuss, H. G., and H. V. Murdaugh. 1968. The toxic effect of ammonia on renal cortical tubule function in vitro. J. Lab. Clin. Med. 71:561-572.

17. Fitzpatrick, J. M., J. R. T. Monson, P. A. Gunter, L. E. Watkinson, and J. E. A. Wickham. 1982. Renal accumulation of ammonia: The cause of post-ischaemic functional loss and the "Blue Line." Br. J. Urol. 54:608-612.

18. Zieve, L. 1982. Hepatic encephalopathy. In Diseases of the Liver. 5th edition. L. Schiff and E. R. Schiff, editors. J. B. Lippincott Company, Philadelphia, 433-460.

19. Lowry, O. H., W. J. Rosebrough, and A. R. Farr. 1951. Protein measurement with the Folin phenol reagent. J. Biol. Chem. 193:265275.

20. Smith, H. W., N. Finkelstein, L. Aliminosa, B. Crawford, and M. Grabor. 1945. Renal clearances of substituted hippuric acid derivatives and other aromatic acids in dog and man. J. Clin. Invest. 24: 388-404.

21. Bauer, J. D. 1982. Clinical Laboratory Methods. 9th Edition. C. V. Mosby Company, St. Louis. 491.

22. Ware, C. F., R. A. Wetzel, and W. P. Kolb. 1981. Physiochemical characterization of fluid phase (SC5b-9) and membrane derived (MC5b9) attack complex of human complement purified by immunoabsorbent affinity chromatography or selective detergent extraction. Mol. Immunol. 18:521-531.

23. Nelson, B., and S. Ruddy. 1979. Enhancing role of IgG in lysis of rabbit erythrocytes by the alternative pathway of human complement. J. Immunol. 122:1994-1999.

24. Mackensen, S., K. E. Grund, M. Sindjic, and A. Bohle. 1979. Influence of the renal cortical interstitium on the serum creatinine concentration and serum creatinine clearance in different chronic sclerosing interstitial nephritides. Nephron. 24:30-34.

25. Mackensen-Haen, S., R. Bader, K. E. Grund, and A. Bohle. 1981. Correlations between renal cortical interstitial fibrosis, atrophy of the proximal tubules and impairment of the glomerular filtration rate. Clin. Nephrol. 15:167-171.

26. Good, D. W., and M. B. Burg. 1984. Ammonia production by individual segments of the rat nephron. J. Clin. Invest. 73:602-610. 
27. Cogan, M. G., and L. Fu-Ying. 1983. Metabolic alkalosis in the rat. Evidence that reduced glomerular filtration rather than enhanced tubular bicarbonate reabsorption is responsible for maintaining the alkalotic state. J. Clin. Invest. 71:1141-1160.

28. Pitts, R. F. 1973. Production and excretion of ammonia in relation to acid-base regulation. Handb. Physiol. (Sect. 8, Renal Physiol.) 455-496.

29. Kolberg, A. 1959. Relations of renal tubular and glomerular function as influenced by 75 percent reduction of nephron number. A pathophysiological study. Scand. J. Clin. Lab. Invest. 11(Suppl. 41):1152.

30. Kramp, R. A., M. MacDowell, C. W. Gottschalk, and J. R. Oliver. 1974. A study by microdissection and micropuncture of the structure and the function of the kidneys and the nephrons of rats with chronic renal damage. Kidney Int. 5:147-176.

31. Falk, R. J., A. P. Dalmasso, Y. Kim, C. H. Tsai, J. I. Schienman, H. Gewurz, and A. F. Michael. 1983. Neoantigen of the polymerized ninth component of complement. Characterization of a monoclonal antibody and immunohistochemical localization in renal disease. J. Clin. Invest. 72:560-573.

32. Salant, D. J., S. Belok, M. P. Madaio, and W. G. Couser. 1980. A new role for complement in experimental membranous nephropathy in rats. J. Clin. Invest. 66:1339-1350.

33. Groggel, G. C., S. Adler, H. G. Rennke, W. G. Couser, and D. J. Salant. 1983. Role of the terminal complement pathway in experimental membranous nephropathy in the rabbit. J. Clin. Invest. 72:1948-1957.

34. Purkerson, M. L., P. E. Hoffsten, and S. Klahr. 1976. Pathogenesis of the glomerulopathy associated with renal infarction in rats. Kidney Int. 9:407-417.

35. Beeson, P. B., and D. Rowley. 1959. The anticomplementary effect of kidney tissue. Its association with ammonia production. $J$. Exp. Med. 110:685-698.

36. Howard, J. B. 1980. Methylamine reaction and denaturationdependent fragmentation of complement component 3. J. Biol. Chem. 255:7082-7084.
37. Tack, B. F., R. A. Harrison, J. Janatova, M. L. Thomas, and J. W. Prahl. 1980. Evidence for presence of an internal thiolester bond in third component of human complement. Proc. Natl. Acad. Sci. USA. 77:5764-5788.

38. Von Zabern, I., R. Nolte, and W. Vogt. 1981. Treatment of human complement components $\mathrm{C} 4$ and $\mathrm{C} 3$ with amines or chaotropic ions. Scand. J. Immunol. 13:413-431.

39. Hostetter, M. K., M. L. Thomas, F. S. Rosen, and B. F. Tack. 1982. Binding of $\mathrm{C} 3 \mathrm{~b}$ proceeds by a transesterification reaction at the thiolester site. Nature (Lond.). 298:72-75.

40. Pangburn, M. K., and H. J. Müller-Eberhard. 1980. Relation of a putative thiolester bond in $\mathrm{C} 3$ to activation of the alternative pathway and the binding of $\mathrm{C} 3 \mathrm{~b}$ to biological targets of complement. J. Exp. Med. 52:1102-1104.

41. Pangburn, M. K., R. D. Schreiber, and H. J. Müller-Eberhard. 1981. Formation of the initial C3 convertase of the alternative complement pathway. J. Exp. Med. 154:856-867.

42. Isenman, D. E., D. I. C. Kells, N. R. Cooper, H. J. MüllerEberhard, and M. K. Pangburn. 1981. Nucleophilic modification of human complement protein C3: correlation of conformational changes with acquisition of $\mathrm{C} 3 \mathrm{~b}$-like functional properties. Biochemistry. 20: 4458-4467.

43. Hostetter, M. K., R. A. Krueger, and D. A. Schmeling. 1984. The biochemistry of opsonization: Central role of the reactive thiolester of C3. J. Infect. Dis. 150: 653-661.

44. Gordon, D. L., R. A. Krueger, P. G. Quie, and M. K. Hostetter. 1985. Amidation of $\mathrm{C} 3$ at the thiolester site: stimulation of phagocytosis and chemiluminescence by a new inflammatory mediator. J. Immunol. 134: 3339-3345.

45. Deen, M. W., and B. Satvat. 1981. Determinants of the glomerular filtration of proteins. Am. J. Physiol. 241:F162-F170.

46. Gardner, K. D. 1961. The effect of $\mathrm{pH}$ on the filtration, reabsorption and excretion of protein by the rat kidney. J. Clin. Invest. 40:525-535. 